\title{
Engagement with tNOX (ENOX2) to Inhibit SIRT1 and Activate p53-Dependent and -Independent Apoptotic Pathways by Novel 4,11-Diaminoanthra[2,3-b]furan- 5,10-diones in Hepatocellular Carcinoma Cells
}

\author{
Chia-Yang Lin ${ }^{1,+}$, Atikul Islam ${ }^{1,+}$, Claire J. Su ${ }^{1,2}$, Alexander S. Tikhomirov ${ }^{3,4}$, \\ Andrey E. Shchekotikhin ${ }^{3,4}$, Show-Mei Chuang ${ }^{1}$, Pin Ju Chueh 1,5,6,*(D) and Yao Li Chen ${ }^{7,8, *}$ \\ 1 Institute of Biomedical Sciences, National Chung Hsing University, Taichung 40227, Taiwan; \\ lcy4534@gmail.com (C.-Y.L.); islammiu555@gmail.com (A.I.); suc1@mca.org.tw (C.J.S.); \\ smchuang@dragon.nchu.edu.tw (S.-M.C.) \\ 2 Morrison Academy in Taichung, 216 Si Ping Road, Taichung 40679, Taiwan \\ 3 Gause Institute of New Antibiotics, 11B. Pirogovskaya Street, 119021 Moscow, Russia; \\ tikhomirov.chem@gmail.com (A.S.T.); shchekotikhin@mail.ru (A.E.S.) \\ 4 Department of Organic Chemistry, Mendeleyev University of Chemical Technology, \\ 9 Miusskaya Square, 125047 Moscow, Russia \\ 5 Graduate Institute of Basic Medicine, China Medical University, Taichung 40402, Taiwan \\ 6 Department of Medical Research, China Medical University Hospital, Taichung 40402, Taiwan \\ 7 Department of General Surgery, Changhua Christian Hospital, Changhua 50008, Taiwan \\ 8 School of Medicine, Kaohsiung Medical University, Kaohsiung 80708, Taiwan \\ * Correspondence: pjchueh@dragon.nchu.edu.tw (P.J.C.); 31560@cch.org.tw (Y.L.C.); \\ Tel.: +886-4-228-40896 (P.J.C.); +886-4-72-38595 (Y.L.C.) \\ + These authors contributed equally to this work.
}

Received: 13 February 2019; Accepted: 21 March 2019; Published: 24 March 2019

\begin{abstract}
Hepatocellular carcinoma (HCC) is the most frequent primary malignancy of the liver and is among the top three causes of cancer-associated death worldwide. However, the clinical use of chemotherapy for HCC has been limited by various challenges, emphasizing the urgent need for novel agents with improved anticancer properties. We recently synthesized and characterized a series of 4,11-diaminoanthra[2,3-b]furan-5,10-dione derivatives that exhibit potent apoptotic activity against an array of cancer cell lines, including variants with multidrug resistance. Their effect on liver cancer cells, however, was unknown. Here, we investigated three selected 4,11-diaminoanthra[2,3-b]furan-5,10-dione derivatives (compounds 1-3) for their cytotoxicity and the underlying molecular mechanisms in wild-type or p53-deficient HCC cells. Cytotoxicity was determined by WST-1 assays and cell impedance measurements and apoptosis was analyzed by flow cytometry. The interaction between compounds and tumor-associated NADH oxidase (tNOX, ENOX2) was studied by cellular thermal shift assay (CETSA). We found that compound $\mathbf{1}$ and $\mathbf{2}$ induced significant cytotoxicity in both HepG2 and Hep3B lines. CETSA revealed that compounds 1 and 2 directly engaged with tNOX, leading to a decrease in the cellular $\mathrm{NAD}^{+} / \mathrm{NADH}$ ratio. This decreased the $\mathrm{NAD}^{+}$-dependent activity of Sirtuin 1 (SIRT1) deacetylase. In p53-wild-type HepG2 cells, p53 acetylation/activation was enhanced, possibly due to the reduction in SIRT1 activity, and apoptosis was observed. In p53-deficient Hep3B cells, the reduction in SIRT1 activity increased the acetylation of c-Myc, thereby reactivating the TRAIL pathway and, ultimately leading to apoptosis. These compounds thus trigger apoptosis in both cell types, but via different pathways. Taken together, our data show that derivatives 1 and 2 of 4,11-diaminoanthra[2,3-b]furan-5,10-diones engage with tNOX and inhibit its oxidase activity. This results in cytotoxicity via apoptosis through tNOX-SIRT1 axis to enhance the acetylation of p53 or c-Myc in HCC cells, depending on their p53 status.
\end{abstract}


Keywords: apoptosis; anthraquinone derivatives; hepatocellular carcinoma; p53; tumor-associated NADH oxidase (tNOX or ENOX2); sirtuin 1 (SIRT1); c-Myc; protein acetylation

\section{Introduction}

Hepatocellular carcinoma (HCC) is the most frequent primary malignancy of the liver and is among the top three most common causes of cancer-associated death worldwide [1,2]. The treatment options for HCC patients include surgical resection, liver transplantation, percutaneous radiofrequency ablation, and either with or without associated chemotherapy [3]. Chemotherapeutic agents bearing an anthracene-9,10-dione moiety, such as doxorubicin, mitoxantrone, valrubicin, etc., are currently used as first-line treatments for HCC patients; the above-named moiety of these agents can interact with DNA duplexes to inhibit topoisomerase 2 (Topo2) and provoke apoptosis [4,5]. However, the clinical use of doxorubicin has been limited by its significant oxidative stress-associated toxicity, low efficacy, and tendency to trigger acquired resistance [6,7]. Thus, it is urgent that we search for and identify novel pharmacological drugs with improved anticancer properties.

We recently reported the synthesis of a series of novel anti-cancer compounds based on furan-fused anthraquinone derivatives that have different side chains, and showed that these derivatives have high antiproliferative activities against various cancer cell lines, including some with resistance to doxorubicin [8-12]. Biological studies revealed that these derivatives exert cytotoxicity via multiple mechanisms, such as by down-regulating a tumor-associated NADH oxidase (tNOX, ENOX2) and Sirtuin 1 (SIRT1) [8]. The human tNOX gene, located on Xq25-26, encodes a protein of 610 amino acids and is universally expressed in an array of cancer/transformed cells derived from solid tumors [13-16]. Overexpression of tNOX in non-cancer cells and its depletion in cancer cells confirmed that $\mathrm{tNOX}$ is essential for and positively associated with cell proliferation and migration [17-21]. In cancer therapy, it is thought that the suppression of $\mathrm{tNOX}$ by various agents (e.g., capsaicin, epigallocatechin gallate, tamoxifen, oxaliplatin) induces apoptosis and attenuates cancer cell growth [19,22-25]. tNOX converts reduced $\mathrm{NADH}$ or hydroquinones to oxidized $\mathrm{NAD}^{+}[14,15,26]$, and recent studies have demonstrated that inhibition of tNOX activity reduces the intracellular $\mathrm{NAD}^{+}$level, which in turn impacts NAD ${ }^{+}$-dependent SIRT1 deacetylase activity and apoptosis $[8,25,27]$.

Although a close correlation between tNOX inhibition and apoptosis has been established in many cancer cell lines, it has not previously been studied in HCC cells. Here, we explored a new therapeutic strategy for HCC by testing the effectiveness of three selected 4,11-diaminoanthra[2,3-b]furan-5,10-diones (compounds 1-3) on p53 wild-type HepG2 and p53-deficient Hep3B cancer cell lines. Given that p53 triggers both cell-autonomous and non-cell-autonomous mechanisms to suppress tumor development in HCC [28], it is not surprising p53 is considered to be a key target for treating HCC. Mutation and misregulation of p53 also leads to an acquired resistance that considerably limits the effectiveness of therapeutic drugs for cancer management. To address these issues, researchers are seeking to identify additional factors in the hopes of designing new therapeutic strategies. Here, using a cellular thermal shift assay (CETSA), we demonstrate that compounds 1 and 2 engage with tNOX and inhibit SIRT1 to induce apoptosis against both p53-wild-type and p53-deficient HCC cell lines.

\section{Results}

\subsection{4,11-Diaminoanthra[2,3-b]furan-5,10-diones 1 and 2 Suppress the Growth of HCC Cells}

We recently reported the synthesis of new anticancer anthra[2,3-b]furan-5,10-dione derivatives with different 4,11 side chains, showed that they potently inhibited the proliferation of various cancer cell lines, including some multidrug resistance sublines with deletion of the p53 gene, and further demonstrated that the cytotoxicity of these agents in cancer cells may be associated with the inhibition 
of tNOX [8]. Given that HCC is one of the top three most common causes of cancer-associated death worldwide, we herein investigated the antiproliferative potency of our new compounds in liver cancer cells and assessed the mechanisms underlying the ability of these compounds to induce apoptosis. We focused on 4,11-diaminoanthra[2,3-b]furan-5,10-dione derivatives 1-3 (Figure 1), which bear ((2-dimethylamino)ethyl)amino, 2-((2-hydroxyethyl)amino)ethylamino, and 2-(guanidino)ethylamino groups, respectively, at their 4,11-positions.<smiles>CN(C)CCNc1c2c(c(NCCN(C)C)c3occc13)C(=O)c1ccccc1C2=O</smiles><smiles>O=C1c2ccccc2C(=O)c2c1c(NCCNCCO)c1ccoc1c2NCCNCCO</smiles><smiles>N=C(N)NCCNc1c2c(c(NCCNC(=N)N)c3occc13)C(=O)c1ccccc1C2=O</smiles>

Figure 1. Structure of 4,11-diaminoanthra[2,3-b]furan-5,10-dione derivatives 1-3.

These derivatives were synthesized in accordance with our previously described scheme [8]. Cell viability assays revealed that compounds $\mathbf{1}$ and $\mathbf{2}$ significantly inhibited the proliferation of HepG2 cells, whereas the derivative bearing terminal guanidine groups on its side chains (compound 3) exhibited no cytotoxicity in this cell line (Figure 2A). Similar results were obtained using cell impedance, which demonstrated that HepG2 cell growth was markedly inhibited by compounds $\mathbf{1}$ and 2 at $2 \mu \mathrm{M}$ over a $70 \mathrm{~h}$ period (Figure 2B). Interestingly, compounds $\mathbf{1}$ and $\mathbf{2}$ also significantly attenuated cell viability and cell growth in p53-deficient HCC Hep3B cells (Figure 2C,D)

These cytotoxic derivatives had little impact on generation of reactive oxygen species (ROS), especially in Hep3B cells, as determined using the fluorescent dye, $\mathrm{H}_{2}$ DCFDA (Figure 2E). The lack of ROS generation in treated HCC cells suggests that the compounds could potentially induce less oxidative stress-mediated cardiomyopathy, which is an adverse effect often found in patients treated with doxorubicin and similar agents $[29,30]$.

\subsection{4,11-Diaminoanthra[2,3-b]furan-5,10-diones 1 and 2 Bind to tNOX and Inhibit $t N O X$-Catalyzed NAD ${ }^{+}$ Generation}

In our previous study, we demonstrated that the newly synthesized 4,11-diaminoanthra[2,3-b] furan-5,10-diones induced apoptosis through tNOX down-regulation; however, the detailed molecular mechanism was not explored [8]. Here, we found that tNOX expression was slightly reduced by compounds 1 and 2, but not by compound 3, in HepG2 and Hep3B cells (Figure 3A). Given that ligand binding normally enhances protein stability [31-33], we employed a cellular thermal shift assay (CETSA) to investigate the interaction of the compounds with tNOX protein. In our CETSA, tNOX proteins incubated with or without compounds were collected, incubated at different temperatures, and recognized by antisera to $\mathrm{tNOX}$ on western blots, which enabled us to plot thermal melting curves and derive the melting temperature $\left(T_{\mathrm{m}}\right.$; the temperature at which $50 \%$ of proteins are unfolded and rapidly precipitated by heat). We found that anthra[2,3-b]furan-5,10-dione 2 elicited an obviously different shift in the thermal melting curves of treated lysates versus untreated lysates from HCC cells. In HepG2 cells, the $T_{\mathrm{m}}$ value increased from $49.1{ }^{\circ} \mathrm{C}$ (control) to $54.5^{\circ} \mathrm{C}$ (treated with compound 2), suggesting that compound $\mathbf{2}$ engaged with tNOX protein and enhanced its thermal stability (Figure 3B). In p53-deficient Hep3B cells, there was also a marked shift in the $T_{\mathrm{m}}$ values between lysates treated with compound 2 and untreated control lysates (Figure 3C) and a greater than 5 degree difference in the $T_{\mathrm{m}}$ of cells treated with and without compound $\mathbf{1}$ (Figure 3D). In contrast, compound $\mathbf{3}$ had little effect (less than 5 degrees) on the thermal melting curves of treated versus untreated cell lysates, suggesting that this compound is incapable of engaging with the tNOX protein in Hep3B cells (Figure 3E). As tNOX catalyzes the conversion of reduced NADH to oxidized $\mathrm{NAD}^{+}[14,15]$, it is relevant that the binding of compound 2 to the tNOX protein resulted in a marked and dose-dependent attenuation of the 
intracellular $\mathrm{NAD}^{+} / \mathrm{NADH}$ ratio in Hep3B cells (Figure 3F). These findings suggest that there is a direct link between the cytotoxicity of anthra[2,3-b]furan-5,10-dione compound 2 and its ability to inhibit tNOX oxidase activity.

A
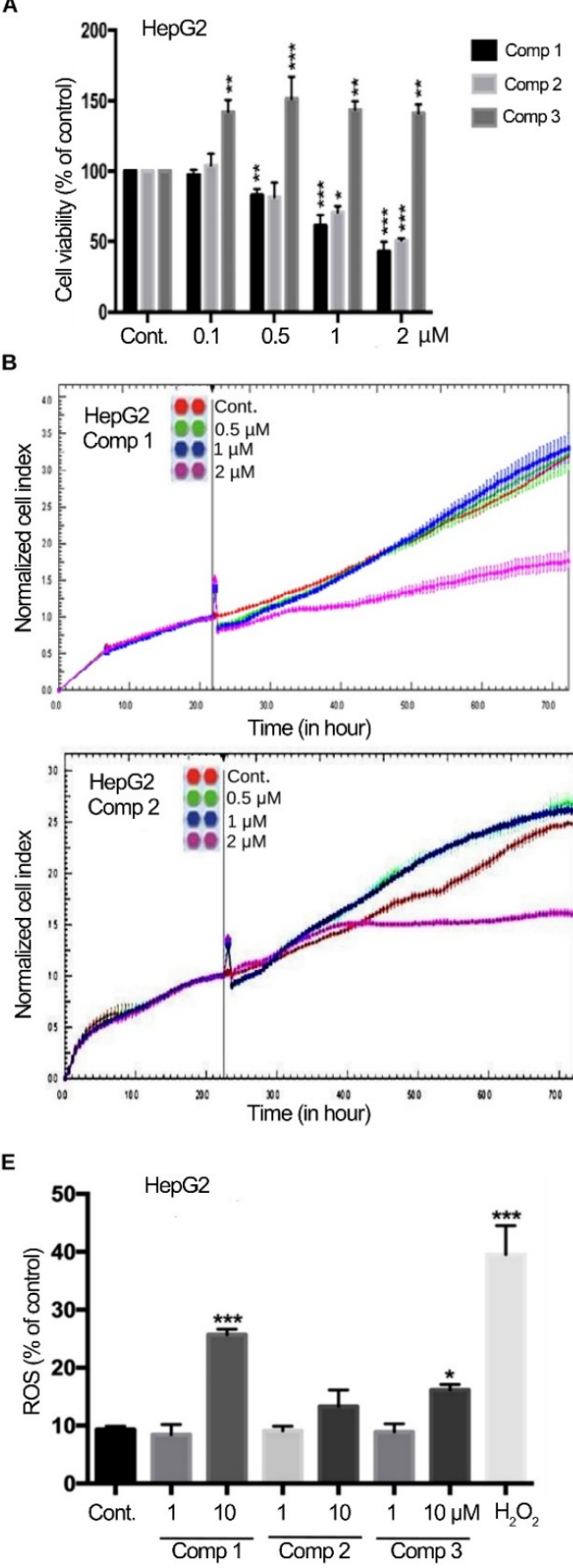

C
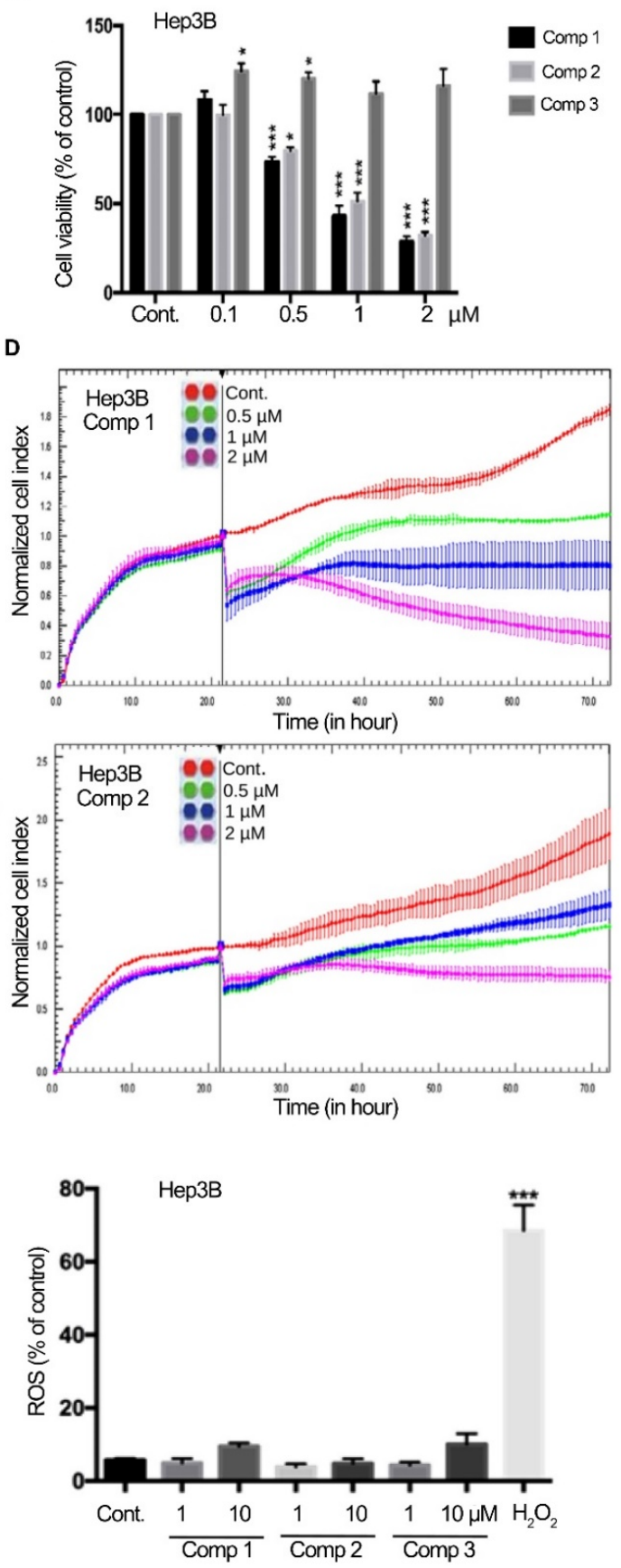

Figure 2. Selected derivatives suppress human hepatocellular carcinoma (HCC) cell viability and growth. (A,C) Cells were exposed to different concentrations of compounds for $24 \mathrm{~h}$ and cell viability was measured using MTS assays (HepG2 in A and Hep3B in C). Values (means \pm SDs) were obtained from at least three independent experiments. There was a significant decrease in cell viability in cells treated with compounds compared with controls $\left({ }^{*} p<0.05\right.$, ${ }^{* *} p<0.01$, $\left.{ }^{* * *} p<0.001\right)$. (B,D) Cells were treated with compounds $\mathbf{1}$ and $\mathbf{2}$ and cell growth was dynamically monitored using impedance technology (HepG2 in B and Hep3B in D). Normalized cell index values measured over $70 \mathrm{~h}$ are shown. (E) The percent change in intracellular reactive oxygen species (ROS) generation was measured after cells were treated for $1 \mathrm{~h}$ with selected derivatives. 


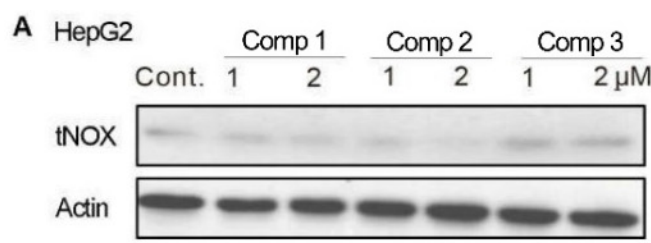

B

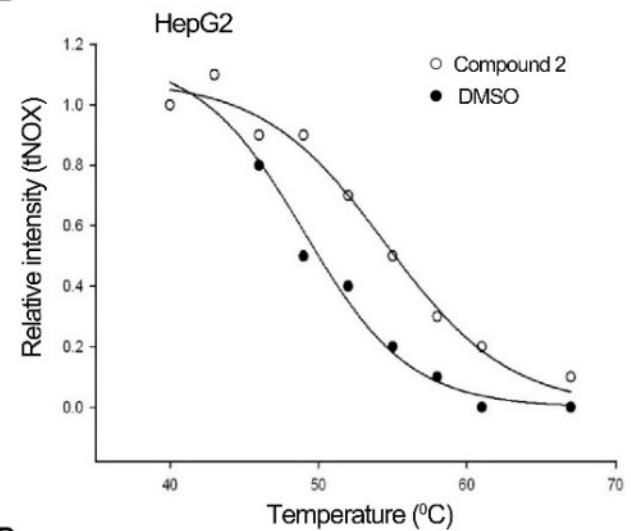

D

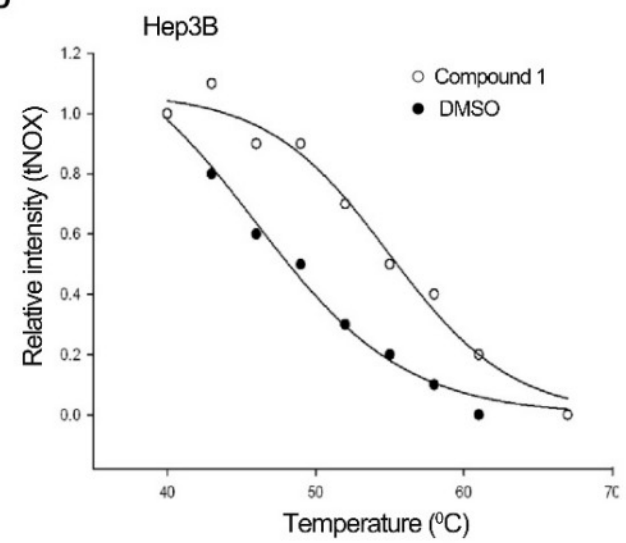

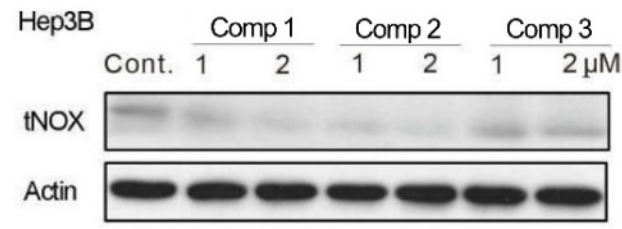

C

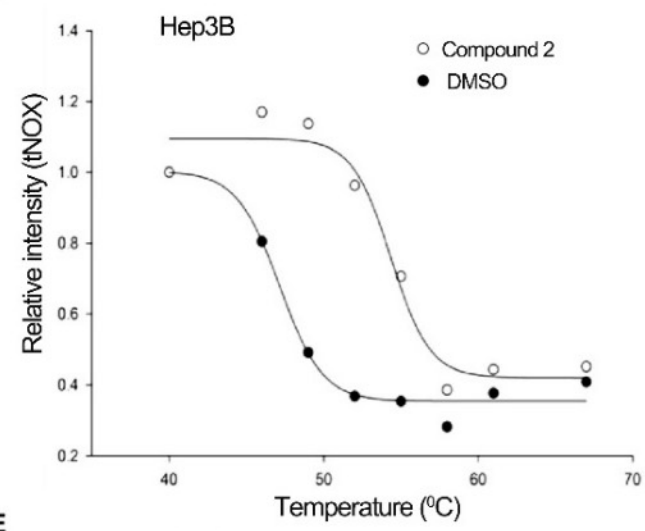

$\mathbf{E}$

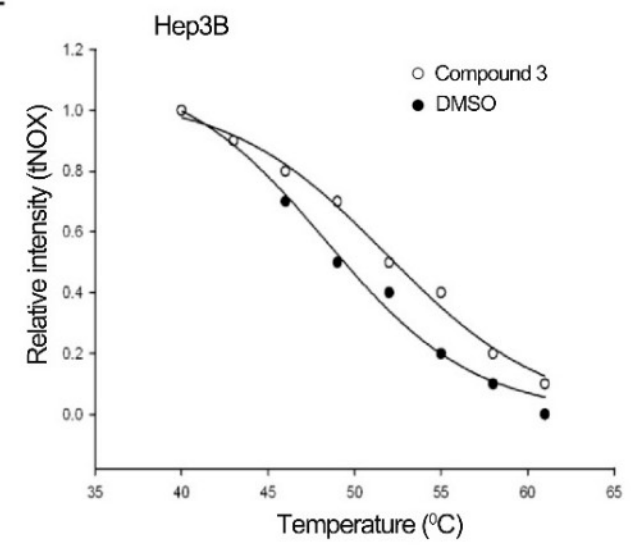

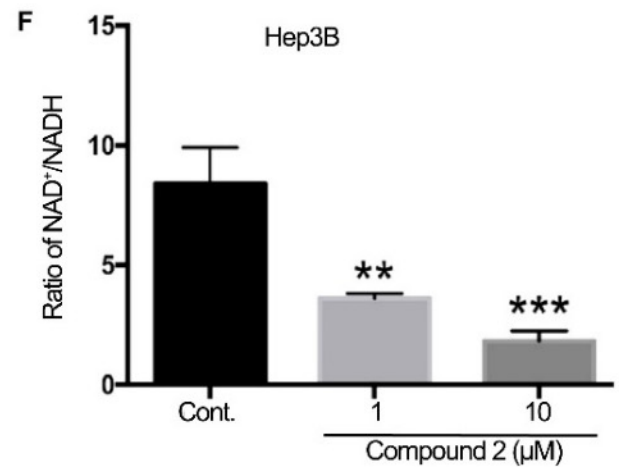

Figure 3. Effects of selected derivatives on tNOX expression and CETSA-based determination of binding between those compounds and tNOX. (A) Cells were treated with different concentrations of compounds or vehicle for $24 \mathrm{~h}$, and cell lysates were separated by SDS-PAGE and analyzed by Western blotting. (B-E) CETSA curves of tNOX in p53-wild-type HepG2 cells (B) and p53-deficient Hep3B cells $(\mathbf{C}, \mathbf{D}, \mathbf{E})$ were determined in the absence and presence of different compounds, and cell lysates were separated by SDS-PAGE and analyzed by western blotting. $\beta$-Actin was used as an internal control. Representative images are shown. The band intensities of $\mathrm{tNOX}$ were normalized with respect to the intensity at $40{ }^{\circ} \mathrm{C}$. The denaturation midpoints were determined using a standard process. (F) Derivative 2 dose-dependently reduces the $\mathrm{NAD}^{+} / \mathrm{NADH}$ ratio in Hep3B cells. Cells were treated with vehicle or compound 2, the $\mathrm{NAD}^{+}$and $\mathrm{NADH}$ levels in cell extracts were quantified based on the optical density at $450 \mathrm{~nm}$, and the $\mathrm{NAD}^{+} / \mathrm{NADH}$ ratio was calculated. Values (mean $\pm \mathrm{SEs}$ ) were obtained from at least three independent experiments. 
2.3. 4,11-Diaminoanthra[2,3-b]furan-5,10-diones 1 and 2 Inhibit SIRT1 Deacetylase Activity and Enhance p53/c-Myc Acetylation, Leading to Apoptosis, Not Autophagy

As the above results indicated that compound 2 slightly attenuated $t$ NOX expression and reduced the intracellular $\mathrm{NAD}^{+} / \mathrm{NADH}$ ratio by engaging with $\mathrm{tNOX}$ in HCC cells, we next sought to understand the cellular outcomes of these changes. As NAD ${ }^{+}$is a cofactor for SIRT1 deacetylase activity, we hypothesized that the compound-induced variation in the intracellular NAD ${ }^{+} / \mathrm{NADH}$ ratio might impact SIRT1 and subsequent cellular events. Our investigations revealed that SIRT1 expression was somewhat diminished by compounds 1 and 2, and that p53 acetylation was markedly enhanced in HepG2 cells exposed to compound 2, possibly due to the reduction in SIRT1 deacetylase activity (Figure 4A). The enhanced p53 acetylation was accompanied by increases in p53 phosphorylation, anti-survival NOXA, PUMA, p21, Bak expression, and PARP cleavage, as well as down-regulation of anti-apoptotic Bcl2, all of which are suggestive of apoptosis (Figure 4A). Indeed, a prominent induction of apoptosis by compound 2 was confirmed by Annexin V-FITC/PI staining followed by flow cytometry (Figure 4B).

A

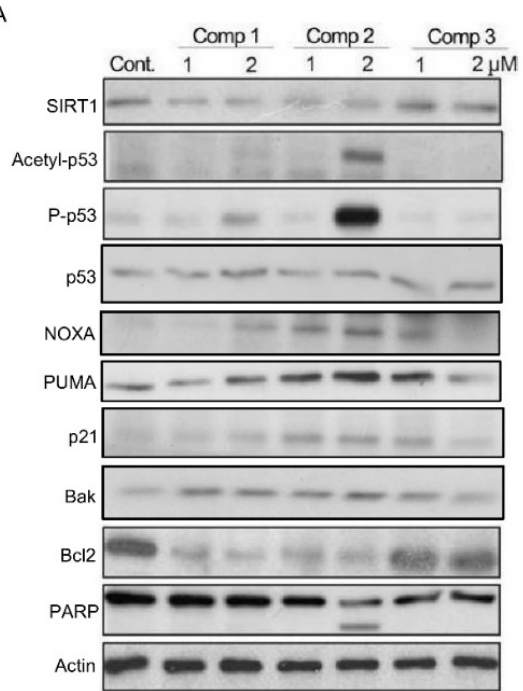

B

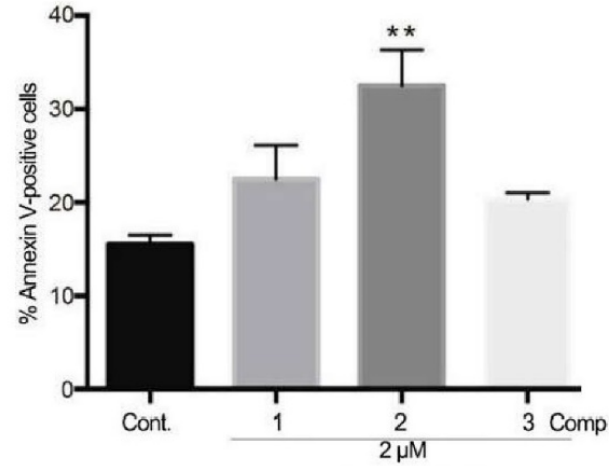

Figure 4. The effects of the selected derivatives on protein expression and apoptosis in HepG2 cells. (A) HepG2 cells were treated with different concentrations of compounds or vehicle for $24 \mathrm{~h}$, and cell lysates were separated by SDS-PAGE and analyzed by western blotting. $\beta$-Actin was used as an internal control. Representative images are shown. (B) Cells were treated with different derivatives for $24 \mathrm{~h}$, and the percentage of apoptotic cells was determined by flow cytometry. The presented values (mean \pm SEs) represent as the percentage of cells in early and late apoptotic populations at least three independent experiments ${ }^{* *} p<0.01$ for treated cells vs. controls). Representative images are shown.

In p53-deficent Hep3B cells, our flow cytometric data confirmed that compounds $\mathbf{1}$ and 2, but not compound 3, triggered marked apoptosis independent of p53 in Hep3B cells (Figure 5A). We also validated that treatment with compounds $\mathbf{1}$ and $\mathbf{2}$ led to slight reduction in SIRT1 expression; moreover, c-Myc acetylation was noticeably enhanced by aminoalkylamino-bearing derivatives 1 and 2, but not guanidine-bearing compound 3, possibly through the ability of the former to suppress SIRT1 deacetylase activity (Figure 5B). The alteration in c-Myc acetylation was accompanied by up-regulation of TRAIL, death receptor 5 (DR5), and pro-apoptotic Bak, down-regulation of pro-survival c-Flip and Bcl-2, and increased caspase 3-directed PARP-cleavage, all of which are consistent with the induction of apoptosis. Interestingly, apoptosis induced by compounds $\mathbf{1}$ and $\mathbf{2}$ was partially blocked by co-treatment with TRAIL-neutralizing antibody, suggesting that these two derivatives triggered TRAIL-death receptor apoptosis signaling pathway (Figure 5C). Conversely, autophagy appears to play an insignificant role in the cytotoxicity induced by these derivatives, even at high concentrations of $10 \mu \mathrm{M}$ (Figure 5D). Lack of marked induction of cleaved LC3-II also supported that compounds 1 and $\mathbf{2}$ are not autophagic (Figure 5E). These various lines of evidences support the notion that the two 
tested novel anthra[2,3-b]furan-5,10-diones inhibit SIRT1 deacetylase activity through p53-dependent and -independent pathways to induce apoptosis.
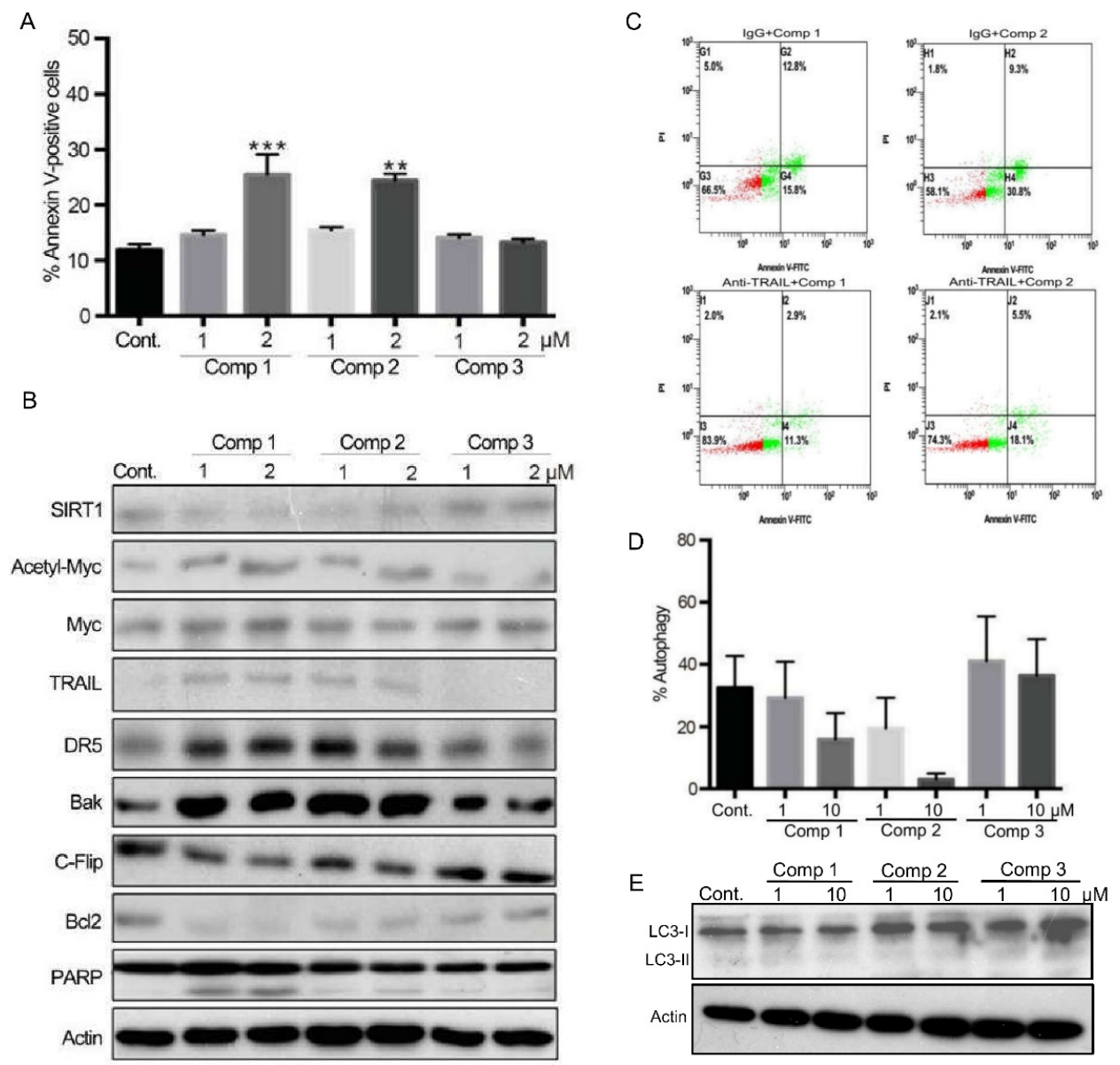

Figure 5. The effects of derivatives on protein expression and cell death in Hep3B cells. (A) Cells were treated with different derivatives for $24 \mathrm{~h}$, and the percentage of apoptotic cells was determined by flow cytometry. $\mathrm{H}_{2} \mathrm{O}_{2}$ treatment was used as a positive control. The presented values (mean $\pm \mathrm{SEs}$ ) represent as the percentage of cells in early and late apoptotic populations at least three independent experiments ${ }^{* *} p<0.01,{ }^{* * *} p<0.001$ for treated cells vs. controls). Representative images are shown. (B) Hep3B cells were treated with different concentrations of compounds or vehicle for $24 \mathrm{~h}$, and cell lysates were separated by SDS-PAGE and analyzed by western blotting. $\beta$-Actin was used as an internal control. Representative images are shown. (C) Cells were pre-treated with IgG or TRAIL-neutralizing antibody at final concentration of $1 \mu \mathrm{L} / \mathrm{mL}$ for one $\mathrm{h}$ before exposed to different derivatives for $24 \mathrm{~h}$. The percentage of apoptotic cells was determined by flow cytometry as described in A. (D) Cells were treated with different compounds or vehicle for $6 \mathrm{~h}$. Autophagy was then determined by AO staining using flow cytometry, and the results are expressed as a percentage relative to the control group. Values (mean $\pm \mathrm{SEs}$ ) were obtained from three independent experiments. (E) Hep3B cells were treated with different concentrations of compounds or vehicle for $24 \mathrm{~h}$, and cell lysates were separated by SDS-PAGE and analyzed by western blotting. $\beta$-Actin was used as an internal control. Representative images are shown.

\section{4. $t$ NOX Expression Is Essential for Hep3B Cell Survival and Correlates with Tumor Progression and Poor Prognosis in an Online Database}

The involvement of $t$ NOX expression in liver cancer cell survival was next evaluated utilizing RNA interference (RNAi) technology in p53-deficient Hep3B cells. We found that transfection with tNOX-specific siRNA effectively reduced tNOX expression compared to that seen in control cells, and that tNOX depletion significantly enhanced spontaneous apoptosis in Hep3B cells compared to untreated control cells (Figure 6). 

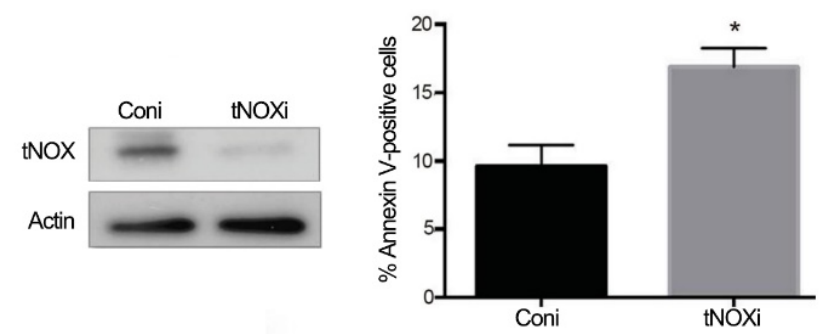

Figure 6. tNOX depletion enhances spontaneous apoptosis in Hep3B cells. tNOX was knocked down by RNA interference in p53-deficient Hep3B cells for $24 \mathrm{~h}$, and the percentage of apoptotic cells was determined by flow cytometry. The presented values (mean \pm SEs) represent at least three independent experiments ( ${ }^{*} p<0.05$ for $\mathrm{tNOX-knockdown}$ cells vs. controls). Representative images are shown.

We further explored the relationship of tNOX (ENOX2) expression in liver hepatocellular carcinoma survival outcomes by data mining in Kaplan-Meier plotter (pan-cancer RNA-seq dataset; www.kmplot.com). Among 249 male patients with liver cancer, high tNOX expression appeared to be associated with a poor prognosis for overall survival [hazard ratio (HR): 1.76, $\log$-rank $p=0.015$ ]. The median overall survival in the low tNOX expression cohort was 82.87 months, compared to 38.3 months in the high tNOX expression cohort (Figure 7A).

A

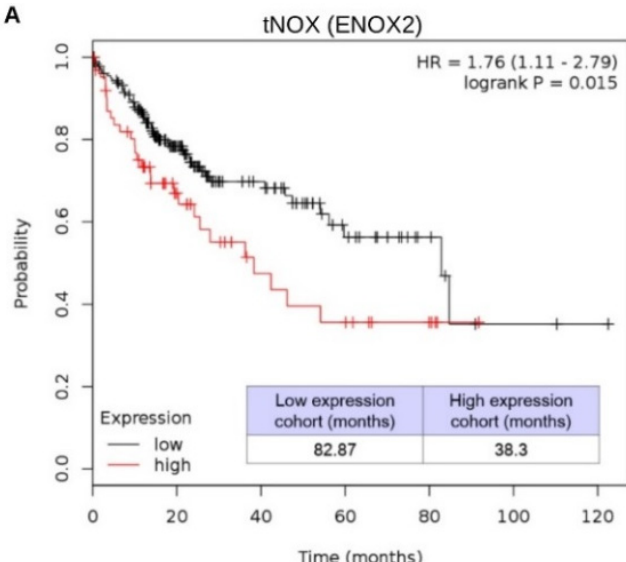

C

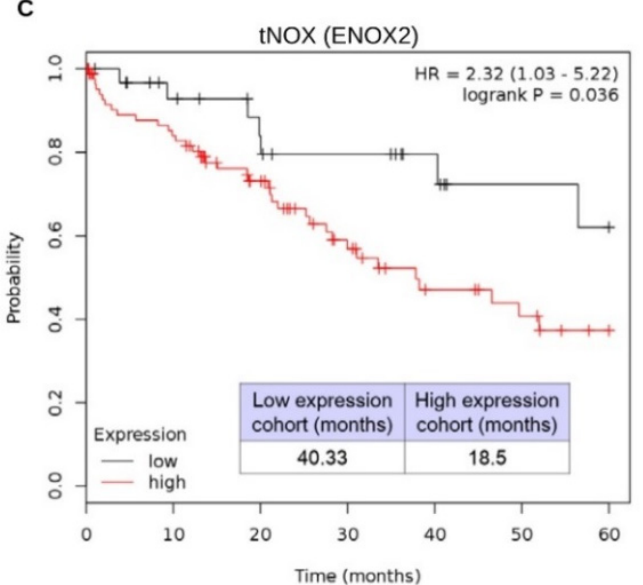

B

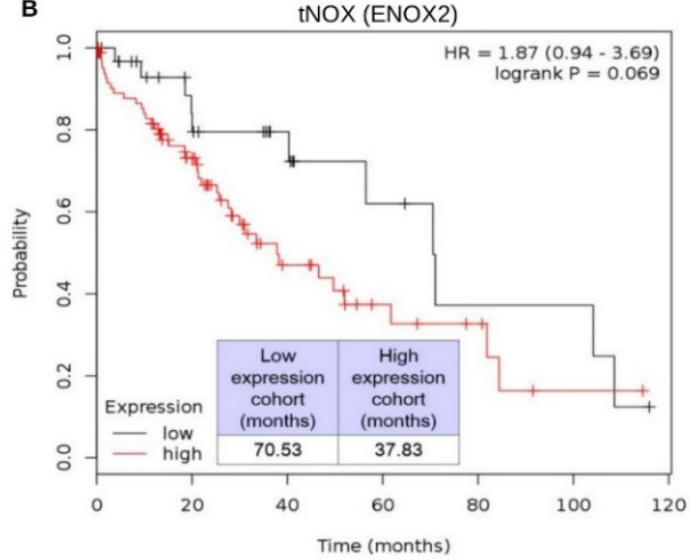

D

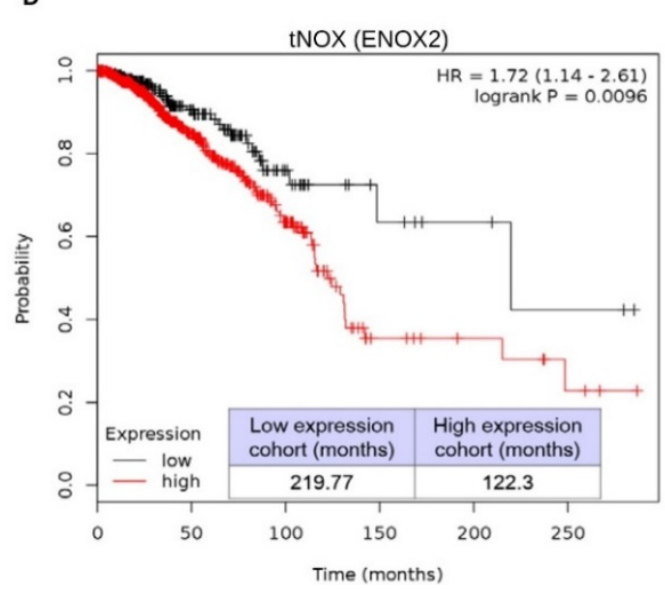

Figure 7. tNOX depletion enhances spontaneous apoptosis in Hep3B cells. tNOX was knocked down by RNA interference in p53-deficient Hep3B cells for $24 \mathrm{~h}$, and the percentage of apoptotic cells High tNOX (ENOX2) expression is associated with worse survival outcomes in liver HCC patients. (A-C) Kaplan-Meier plots of the association between ENOX2 expression and overall survival in male (A) and female (B,C) liver cancer patients. (D) Kaplan-Meier plots of the association between ENOX2 expression and overall survival in female breast cancer patients. Data were obtained using Kaplan-Meier Plotter. 
An insignificant correlation was found between high tNOX expression and decreased overall survival in 121 female patients (HR: 1.87, log-rank $p=0.069$ ), but the median survival was much lower in the high tNOX expression cohort (37.83 months) compared to the low tNOX expression cohort (70.53 months) (Figure 7B). Notably, low tNOX expression was significantly correlated with better survival outcomes if the follow-up threshold was adjusted to 60 months in the same female population (HR: 2.32, log-rank $p=0.036$ ). The upper quartile survival was 40.33 months in the low tNOX expression cohort, which was significantly longer than the 18.5 months seen in the low tNOX expression cohort (Figure 7C). Beyond HCC, a striking negative correlation between tNOX expression and prognosis was found in female patients with breast cancer (HR: 1.72, log-rank $p=0.0096$ ) (Figure 7D).

Together, our various lines of evidence suggest that tNOX expression is positively correlated with worse survival outcomes, and that this high expression can be suppressed by anti-neoplastic 4,11-diaminoanthra[2,3- $b$ ]furan-5,10-diones or RNA interference to induce apoptosis. The novel derivatives tested herein exert their apoptotic activity by engaging with tNOX to reduce NADH oxidation, which inhibits SIRT1 deacetylase activity. In p53 wild-type HCC cells, this activates p53; in p53-deficent Hep3B cells, it increases c-Myc acetylation to up-regulate TRAIL expression, which also leads to apoptosis (Figure 8).

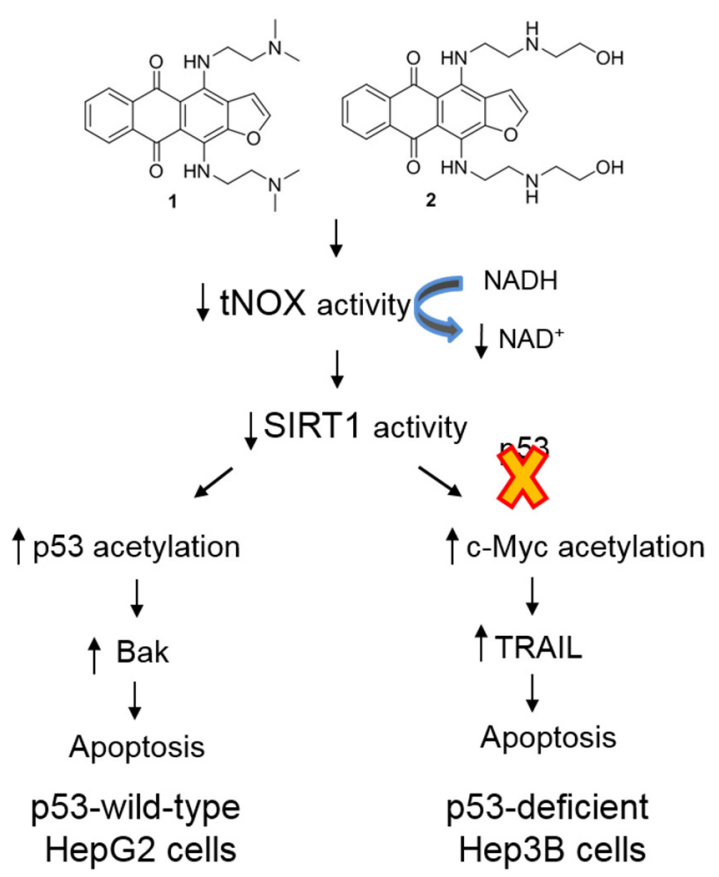

Figure 8. Schematic diagram of the pathways that lead to the different pathways of p53-wild-type HepG2 and p53-deficient Hep3B cells by 4,11-diaminoanthra[2,3-b]furan-5,10-diones 1 and 2.

\section{Discussion}

We report that two novel 2-unsubstituted 4,11-diaminoanthra[2,3-b]furan-5,10-dione derivatives, herein called compounds 1 and 2, induce potent cytotoxicity in human HCC cells by triggering apoptosis. We show that the apoptotic potency of these derivatives results from their engagement with $\mathrm{tNOX}$, a tumor-associated NADH oxidase, which in turn reduces the intracellular NAD ${ }^{+} / \mathrm{NADH}$ ratio. This suppresses $\mathrm{NAD}^{+}$-dependent SIRT1 deacetylase activity, leading to enhanced p53 acetylation/activation and apoptosis in HepG2 cells. Alternatively, in p53-deficient Hep3B cells, we observe increased c-Myc acetylation; this up-regulates TRAIL, which is essential for apoptosis induction (Figure 8). Our results collectively suggest that anthrafurandione compounds $\mathbf{1}$ and 2, whose side chains resemble those of the mitoxantrone, ((2-dimethylamino)ethyl)amino and 2-((2-hydroxyethyl)amino)ethylamino, respectively, show antiproliferative potency against human HCC cells. The clinical use of anthracycline chemotherapeutics, including doxorubicin, in cancer 
treatment has been complicated by cardiotoxicity [34-36]. Although there is still debate on this matter, many lines of evidence indicate that anthracycline-mediated cardiotoxicity is associated with mitochondrial abnormalities and oxidative stress [37,38]. In this context, it is notable that compounds $\mathbf{1}$ and $\mathbf{2}$ failed to induce high-level ROS generation in Hep3B cells; thus, their clinical use may result in fewer cardiomyopathic adverse effects. In contrast to compounds $\mathbf{1}$ and $\mathbf{2}$, compound 3, which bore guanidinated terminal amino groups, had far less cytotoxic potential, probably due to its overly high positive charge and subsequent reduced binding with intracellular targets. Indeed, we observed a correlation between low tNOX engagement and the absence of cytotoxicity for compound 3 . It is also possible that the introduction of guanidine resides in the side chains of anthrafurandiones and related anthraquinones may decrease their uptake and cellular distribution $[8,10,11]$.

An array of well-known anti-cancer agents, including capsaicin, tea catechin, doxorubicin, and phenoxodiol, have been shown to exert their anti-neoplastic activities by inhibiting or down-regulating tNOX to induce apoptosis $[19,22-24,39,40]$. However, no previous work has shown that tNOX engages with such drugs to achieve its therapeutic effects. Here, we used CETSA to directly assess the changes in tNOX upon exposure of anthra[2,3-b]furan-5,10-diones $\mathbf{1}$ and 2 but not 3. After heating, it appeared that the treatment of cells with compounds $\mathbf{1}$ or $\mathbf{2}$ prevented tNOX from becoming denatured and precipitated; instead, the ligand-bound complexes remained in solution to be visualized by western blot analysis. This engagement inhibited the ability of tNOX to oxidize the reduced form of $\mathrm{NADH}$, leading to decreases in $\mathrm{NAD}^{+}$generation and SIRT1 deacetylase activity, which ultimately resulted in apoptosis and inhibition of cancer cell growth. Similar findings by another study [41] clearly suggest that tNOX-oxaliplatin binding interferes with its oxidase activity and plays a critical role in regulating apoptosis. Using in vitro cell models, we confirmed that tNOX depletion restored non-cancer phenotypes, including abrogated anchorage-independent growth, increased sensitivity to stress-mediated apoptosis, attenuated migration, and prolonged cell cycle progression, further supporting the importance of tNOX in cancer management $[17,19,21,25,42]$.

Another significant contribution of this work is our evidence showing that the tested derivatives activate differential cellular responses to induce apoptosis in p53-dependent and -independent fashions. In p53-wild-type HepG2 cells, we found that binding between tNOX and compound 2 reduced the intracellular $\mathrm{NAD}^{+}$concentration, resulting in SIRT1 inhibition and enhancement of p53 acetylation, which in turn up-regulated its downstream target, pro-apoptotic Bak. Consistent with our results, the increased p53 acetylation that follows SIRT1 inhibition was shown to be associated with an induction of PUMA, which up-regulates Bak and triggers apoptosis [43]. Inspired by a recent study revealing that acetylated c-Myc loses its ability to impair TRAIL expression [44], we also investigated c-Myc. Indeed, in p53-deficient Hep3B cells, we found that compounds $\mathbf{1}$ and $\mathbf{2}$ both enhanced c-Myc acetylation with concurrent TRAIL up-regulation and apoptosis. Our finding of increased apoptosis in Hep3B cells treated with compounds $\mathbf{1}$ and $\mathbf{2}$ is consistent with a previous report showing that the inhibition of SIRT1 is linked to DR5 up-regulation and c-Flip suppression, which sensitizes human leukemic K562 cells to apoptosis [45]. Interestingly, c-Myc has been shown to induce SIRT1 at the transcriptional or posttranscriptional levels, and SIRT1 was found to interact with and deacetylate c-Myc [46,47]. Although there is some debate regarding how SIRT1-mediated deacetylation affects the stability of c-Myc, it is clear that a c-Myc-SIRT1 feedback loop significantly impacts cell growth and transformation [46-49]. Our present results agree with the previous findings by showing that the SIRT1-inhibition-mediated enhancement of c-Myc acetylation is accompanied by up-regulation of TRAIL and DR5, supporting the idea that SIRT1 plays a tumor-promoting role in the context of c-Myc activation [50,51].

It has been well documented that tNOX positively regulates cell proliferation and migration [17-21], but much less is known regarding the expression and the related clinical outcomes. Previous work showed that anti-cancer drug treatments suppressed the tNOX activity observed in pooled sera of cancer patients but not non-cancer-bearing volunteers [52-54]. Using data mining in Kaplan-Meier plotter (www.kmplot.com), we herein observed that the overall survival in 370 patients 
with liver cancer tended to be correlated with tNOX expression, although not to a significant degree. The median overall survival in the low tNOX expression cohort was 61.73 months, compared to 46.2 months in the high tNOX expression cohort (HR: 1.37, log-rank $p=0.11$ ). When we separated the patients by gender, we found that tNOX expression was significantly correlated with poor prognosis in male patients, but not in female patients (Figure 7A,B), suggesting that gender is a key factor that affects survival outcomes. This finding is not surprising, given that the tNOX gene resides on the $\mathrm{X}$ chromosome [13] and previous work showed that gender influences the survival of colorectal cancer patients [55,56]. Thus, the gender-related differences in clinical outcomes may reflect a dosage effect on genes expressed from sex chromosomes [57]. Using the online EMBL-EBI database (http:/ / www.ebi.ac.uk/gxa), we found that tNOX (ENOX2) expression was 2 Log2-fold enhanced in specimens from primary colorectal tumor patients with and without distant metastasis, as assessed in a microarray analysis [58]. Interestingly, a previous study found that the use of hepatocyte growth factor to induce the epithelial-mesenchymal transition (EMT) was associated with significant induction of tNOX expression in small cell lung cancer cells [59]. This was consistent with our previous proposal that up-regulation of tNOX enhances cell migration and EMT [24]. tNOX expression has also been positively associated with lymphangiogenesis, and high-level tNOX-expression was found to be associated with very metastatic phenotypes in a population of melanoma patients [60]. These converging lines of evidence strongly suggest that tNOX must be suppressed in order for a patient to have a better prognosis.

In sum, we herein used CETSA to show that tNOX directly engages with two novel anthraquinone derivatives to mediate different pathways that can lead to apoptosis even in a p53-inactivated system. Our experimental findings and the results of our clinical data mining collectively indicate that tNOX could be a useful therapeutic drug target. These novel anthraquinone-derived compounds inhibit tNOX-NAD ${ }^{+}$-SIRT1 axis to induce apoptosis, highlighting the value of $\mathrm{tNOX}$ as a possible therapeutic target and implying future clinical use of these compounds in cancer treatment without considering p53 expression.

\section{Materials and Methods}

\subsection{Materials}

Fetal bovine serum (FBS) and penicillin/streptomycin were obtained from Gibco/BRL Life Technologies (Grand Island, NY, USA). The anti-Bak, anti-Bcl-2, anti-PARP, anti-p53, anti-phospho-p53, anti-acetyl-p53, anti-Noxa, anti-PUMA, anti-TRAIL, anti-DR5, anti-C-Flip and anti-SIRT1 antibodies were purchased from Cell Signaling Technology, Inc. (Beverly, MA, USA). The anti-p21 and anti-Myc antibody were purchased from Santa Cruz Biotechnology, Inc. (Santa Cruz, CA, USA). The anti-acetyl-Myc and $\beta$-actin antibody were from EMD Millipore, Inc. (Burlington, MA, USA). The antisera to tNOX used in our western blot analyses were generated as described previously [18]. The anti-mouse and anti-rabbit IgG antibodies and other chemicals were purchased from Sigma Chemical Company (St. Louis, MO, USA) unless otherwise specified.

\subsection{Chemistry}

4,11-Diaminoanthra[2,3-b]furan-5,10-dione derivatives 1-3 were prepared in accordance with the previously described procedure [8]. The purities of the tested samples of $\mathbf{1}-\mathbf{3}$ were $>95 \%$, as determined by HPLC analysis.

\subsection{Cell Culture and Transfection}

HepG2 (p53 wild-type) (The Bioresource Collection and Research Center, BCRC, Hsinchu, Taiwan) and Hep3B (p53-deficent, derived from human HCC) (ATCC, Manassas, VA, USA) were grown in MEM supplemented with $10 \%$ fetal bovine serum, 100 units $/ \mathrm{mL}$ penicillin and $50 \mu \mathrm{g} / \mathrm{mL}$ streptomycin. The cells were grown at $37{ }^{\circ} \mathrm{C}$ in a humidified atmosphere of $5 \% \mathrm{CO}_{2}$ in air, with replacement of the 
medium every 2-3 days. The experimental groups were treated with different concentrations of the test compounds dissolved in DMSO, and the controls were treated with the same volume of DMSO.

ON-TARGETplus tNOX (ENOX2) siRNA and negative control siRNA were purchased from Thermo Scientific, Inc. (Grand Island, NY, USA). Briefly, cells were seeded in 10-cm dishes, allowed to attach overnight, and then transfected with tNOX siRNA or control siRNA using the Lipofectamine RNAiMAX Reagent (Gibco/BRL Life Technologies) according to the manufacturer's instructions.

\subsection{Continuous Monitoring of Cell Impedance}

For continuous monitoring of changes in cell growth, cells $\left(7.5 \times 10^{3}\right.$ cells/well) were seeded onto E-plates and incubated for $30 \mathrm{~min}$ at room temperature. The E-plates were placed onto a Real-Time Cell Analysis (RTCA) station (ACEA Biosciences, Inc. San Diego, CA, USA) and the cells were grown overnight before being exposed to test compounds or $\mathrm{ddH}_{2} \mathrm{O}$. Cell impedance was defined by the cell index $(C I)=\left(Z_{i}-Z_{0}\right)[O h m] / 15[O h m]$, where $Z_{0}$ is the background resistance and $Z_{i}$ is the resistance at an individual time point. $\mathrm{CI}$ readouts were initiated after the cell seeding and measurements were taken every hour for a total of $72 \mathrm{~h}$. The results are reported as normalized CI values, which were determined as the $\mathrm{CI}$ at a certain time point divided by that at the beginning of the exposure.

\subsection{Cell Viability Assay}

Cells $\left(5 \times 10^{3}\right)$ were seeded in 96-well culture plates in medium containing $10 \%$ serum, incubated overnight at $37^{\circ} \mathrm{C}$, and treated with test compounds. At the end of the treatment period, cell viability was determined using the WST-1 reagent (Roche) as described by the manufacturer. All experiments were performed at least in triplicate on three separate occasions. Data are presented as means \pm SDs.

\subsection{Apoptosis Determination}

Apoptosis was measured using an Annexin V-FITC apoptosis detection kit (BD Pharmingen, San Jose, CA, USA). For the TRAIL-neutralization experiment, cells were pre-treated with IgG or anti-TRAIL antibody (Cell Signaling Technology) to a final concentration of $1 \mu \mathrm{L} / \mathrm{mL}$ for one h before exposed to different derivatives for $24 \mathrm{~h}$. Cells cultured in 6-cm dishes were trypsinized, collected by centrifugation, washed, resuspended in $1 \times$ binding buffer, and stained with Annexin V-FITC, as recommended by the manufacturer. Cells were also stained with propidium iodide (PI) for detection of necrosis or late apoptosis. The distributions of viable (FITC/PI double-negative), early apoptotic (FITC-positive), late apoptotic (FITC/PI double-positive), and necrotic (PI-positive/FITC-negative) cells were analyzed using a FC500 flow cytometer (Beckman Coulter, Inc., Indianapolis, IN, USA). The results are expressed as a percentage of total cells.

\subsection{Measurement of Intracellular $\mathrm{NAD}^{+} / \mathrm{NADH}$ Ratio}

The oxidized and reduced forms of intracellular NAD were determined using an NADH/NAD Quantification Kit (BioVision Inc., Milpitas, CA, USA), as described by the manufacturer. Briefly, $2 \times 10^{5}$ cells were washed with cold PBS, pelleted, and extracted by two freeze/thaw cycles with $400 \mu \mathrm{L}$ of $\mathrm{NADH} / \mathrm{NAD}^{+}$extraction buffer. The samples were vortexed and centrifuged at $14,000 \mathrm{rpm}$ for $5 \mathrm{~min}$. The extracted $\mathrm{NADH} / \mathrm{NAD}^{+}$supernatant $(200 \mu \mathrm{L})$ was transferred to a microcentrifuge tube, heated to $60^{\circ} \mathrm{C}$ for $30 \mathrm{~min}$ (to decompose $\mathrm{NAD}^{+}$but not $\mathrm{NADH}$ ), and placed on ice. The samples were then centrifuged and transferred to a multiwell-plate. Standards and a NAD ${ }^{+}$ cycling mix were prepared according to the manufacturer's protocol. The reaction mix $(100 \mu \mathrm{L})$ was distributed to each well containing NADH standards and samples, and the plates were incubated at room temperature for $5 \mathrm{~min}$ to convert $\mathrm{NAD}^{+}$to $\mathrm{NADH}$. The provided NADH developer solution was dispensed to each well, and plates were incubated at room temperature for 15 or $30 \mathrm{~min}$. The reaction was stopped with $10 \mu \mathrm{L}$ of stop solution per well, and absorbance was measured at $450 \mathrm{~nm}$. 


\subsection{Cellular Thermal Shift Assay (CETSA)}

Engagement between each compound and tNOX in cells was analyzed by CETSA. Samples were prepared from control and drug-exposed cells. For each set, $2 \times 10^{7}$ cells were seeded in a 10-cm cultured dish. After $24 \mathrm{~h}$ of culture, the cells were pretreated with $10 \mu \mathrm{M}$ MG132 for $1 \mathrm{~h}$, washed with PBS, treated with trypsin, and collected. Samples were centrifuged at 12,000 rpm for $2 \mathrm{~min}$ at room temperature, the pellets were gently resuspended with $1 \mathrm{~mL}$ of PBS, and the samples were centrifuged at $7500 \mathrm{rpm}$ for $3 \mathrm{~min}$ at room temperature. The pellets were resuspended with $1 \mathrm{~mL}$ of PBS containing $20 \mathrm{mM}$ Tris-HCl pH 7.4, $100 \mathrm{mM} \mathrm{NaCl}, 5 \mathrm{mM}$ EDTA, $2 \mathrm{mM}$ phenylmethylsulfonyl fluoride (PMSF), $10 \mathrm{ng} / \mathrm{mL}$ leupeptin, and $10 \mu \mathrm{g} / \mathrm{mL}$ aprotinin. The samples were transferred to Eppendorf tubes and subjected to three freeze-thaw cycles; for each cycle, they were exposed to liquid nitrogen for $3 \mathrm{~min}$, placed in a heating block at $25^{\circ} \mathrm{C}$ for $3 \mathrm{~min}$, and vortexed briefly. The samples were then centrifuged at $12,000 \mathrm{rpm}$ for $30 \mathrm{~min}$ at $4{ }^{\circ} \mathrm{C}$, and the supernatants were transferred to new Eppendorf tubes. For the experimental sample set, each test compound was added to a final concentration of $100 \mu \mathrm{M}$; for the control sample set, the same volume of vehicle solvent was added. The samples were heated at $37^{\circ} \mathrm{C}$ for $1 \mathrm{~h}$ and dispensed to $100 \mu \mathrm{L}$ aliquots. Pairs consisting of one control aliquot and one experimental aliquot were heated at $40^{\circ} \mathrm{C}, 43^{\circ} \mathrm{C}, 46^{\circ} \mathrm{C}, 49^{\circ} \mathrm{C}, 52{ }^{\circ} \mathrm{C}, 55^{\circ} \mathrm{C}, 58^{\circ} \mathrm{C}, 61^{\circ} \mathrm{C}$, or $67^{\circ} \mathrm{C}$ for 3 min. Finally, the samples were placed on ice and subjected to western blot analysis using antisera to tNOX $[18,61]$.

\subsection{Measurement of Reactive Oxygen Species (ROS)}

Oxidative stress was determined by measuring the level of hydrogen peroxide $\left(\mathrm{H}_{2} \mathrm{O}_{2}\right)$ generated in the cells, as assessed by 5-(6)-carboxy-2', $7^{\prime}$-dichlorodihydrofluorescein diacetate (carboxy- $\mathrm{H}_{2} \mathrm{DCFDA}$ ) staining. The nonpolar, nonionic $\mathrm{H}_{2}$-DCFDA is cell permeable and is hydrolyzed to nonfluorescent $\mathrm{H}_{2}$-DCF by intracellular esterases. In the presence of peroxide, $\mathrm{H}_{2}-\mathrm{DCF}$ is rapidly oxidized to highly fluorescent DCF. In brief, at the end of test compound treatment, cells $\left(2 \times 10^{5}\right)$ were washed with PBS and incubated with $5 \mu \mathrm{M} \mathrm{H}_{2}$ DCFDA in DMSO for $30 \mathrm{~min}$. The cells were then collected by trypsinization and centrifugation, washed with PBS, centrifuged at $200 \times g$ for 5 min and analyzed immediately using a Beckman Coulter FC500 flow cytometer.

\subsection{Western Blot Analysis}

Cell extracts were prepared in lysis buffer containing $20 \mathrm{mM}$ Tris- $\mathrm{HCl}$ pH 7.4, $100 \mathrm{mM} \mathrm{NaCl}$, $5 \mathrm{mM}$ EDTA, $2 \mathrm{mM}$ PMSF, $10 \mathrm{ng} / \mathrm{mL}$ leupeptin, and $10 \mu \mathrm{g} / \mathrm{mL}$ aprotinin. Equal amounts of extracted proteins $(40 \mu \mathrm{g})$ were resolved by SDS-PAGE and transferred to nitrocellulose membranes (Schleicher \& Schuell, Keene, NH, USA). The membranes were blocked with nonfat milk solution for $1 \mathrm{~h}$, and then washed and probed with the appropriate primary antibody. The membranes were rinsed with Tris-buffered saline containing $0.1 \%$ Tween 20 , incubated with horseradish peroxidase-conjugated secondary antibody for $1 \mathrm{~h}$, rinsed again, and developed using enhanced chemiluminescence (ECL) reagents (Amersham Biosciences, Piscataway, NJ, USA).

\subsection{Statistics}

All data are expressed as the means \pm SEs of three or more independent experiments. Between-group comparisons were performed using one-way analysis of variance (ANOVA) followed by an appropriate post-hoc test. A value of $p<0.05$ was considered to be statistically significant.

\section{Conclusions}

In the present study, we focused on the apoptotic pathways that are induced by selected novel anthraquinone derivatives in human hepatocellular carcinoma cells that differ in their p53 status. In p53-wild-type HepG2 cells, binding of the drug to tNOX was found to interfere with tNOX-NAD ${ }^{+}$-SIRT1 activation, leading to $\mathrm{p} 53$ acetylation/activation and apoptosis. In p53-deficient Hep3B cells, on the other hand, inhibition of the tNOX-NAD ${ }^{+}-$SIRT1 axis increased c-Myc acetylation, 
which up-regulated TRAIL and DR5 expression to induce apoptosis. Based on these findings, we proposed that targeting of tNOX may be a potential strategy for cancer therapy in both p53-dependent and -inactivated systems and the tested compounds can be explored further as therapeutics against cancer.

Author Contributions: Conceptualization, P.J.C. and Y.L.C.; Data curation, C.-Y.L., A.I., C.J.S., S.-M.C. and P.J.C.; Formal analysis, C.-Y.L., A.I., A.S.T., A.E.S. and P.J.C.; Funding acquisition, A.S.T., A.E.S. and P.J.C.; Investigation, C.-Y.L., A.I. and C.J.S.; Methodology, C.-Y.L., A.I., C.J.S. and S.-M.C.; Project administration, P.J.C.; Resources, A.S.T., A.E.S., P.J.C. and Y.L.C.; Supervision, P.J.C.; Validation, A.I. and C.J.S.; Visualization, C.-Y.L., A.I., S.-M.C. and P.J.C.; Writing—original draft, A.S.T. and P.J.C.; Writing—review \& editing, A.S.T., A.E.S., P.J.C. and Y.L.C.

Funding: This work was supported by grants from the Grants Council of the President of the Russian Federation for state support of young Russian scientists (MK-2474.2018.3 to A.S.T.) and the Ministry of Sciences and Technology, Taiwan (MOST 106-2320-B-005-008-MY3 and MOST 108-2923-B-005-001-MY3 to P.J.C.).

Conflicts of Interest: The authors declare no conflict of interest.

\section{References}

1. Altekruse, S.F.; McGlynn, K.A.; Reichman, M.E. Hepatocellular carcinoma incidence, mortality, and survival trends in the United States from 1975 to 2005. J. Clin. Oncol. 2009, 27, 1485-1491. [CrossRef] [PubMed]

2. El-Serag, H.B. Epidemiology of viral hepatitis and hepatocellular carcinoma. Gastroenterology 2012, 142, 1264-1273. [CrossRef]

3. Varela, M.; Sala, M.; Llovet, J.M.; Bruix, J. Treatment of hepatocellular carcinoma: Is there an optimal strategy? Cancer Treat. Rev. 2003, 29, 99-104. [CrossRef]

4. Tewey, K.M.; Chen, G.L.; Nelson, E.M.; Liu, L.F. Intercalative antitumor drugs interfere with the breakage-reunion reaction of mammalian DNA topoisomerase II. J. Biol. Chem. 1984, 259, 9182-9187.

5. Fornari, F.A.; Randolph, J.K.; Yalowich, J.C.; Ritke, M.K.; Gewirtz, D.A. Interference by doxorubicin with DNA unwinding in MCF-7 breast tumor cells. Mol. Pharmacol. 1994, 45, 649-656. [PubMed]

6. Ganne-Carrie, N.; Trinchet, J.C. Systemic treatment of hepatocellular carcinoma. Eur. J. Gastroenterol. Hepatol. 2004, 16, 275-281. [CrossRef] [PubMed]

7. Cox, J.; Weinman, S. Mechanisms of doxorubicin resistance in hepatocellular carcinoma. Hepat. Oncol. 2016, 3, 57-59. [CrossRef] [PubMed]

8. Tikhomirov, A.S.; Shchekotikhin, A.E.; Lee, Y.H.; Chen, Y.A.; Yeh, C.A.; Tatarskiy, V.V., Jr.; Dezhenkova, L.G.; Glazunova, V.A.; Balzarini, J.; Shtil, A.A.; et al. Synthesis and Characterization of 4,11-Diaminoanthra[2,3-b]furan-5,10-diones: Tumor Cell Apoptosis through tNOX-Modulated $\mathrm{NAD}^{+}$/NADH Ratio and SIRT1. J. Med. Chem. 2015, 58, 9522-9534. [CrossRef]

9. Shchekotikhin, A.E.; Dezhenkova, L.G.; Tsvetkov, V.B.; Luzikov, Y.N.; Volodina, Y.L.; Tatarskiy, V.V., Jr.; Kalinina, A.A.; Treshalin, M.I.; Treshalina, H.M.; Romanenko, V.I.; et al. Discovery of antitumor anthra[2,3-b]furan-3-carboxamides: Optimization of synthesis and evaluation of antitumor properties. Eur. J. Med. Chem. 2016, 112, 114-129. [CrossRef] [PubMed]

10. Miglietta, G.; Cogoi, S.; Marinello, J.; Capranico, G.; Tikhomirov, A.S.; Shchekotilthin, A.; Xodo, L.E. RNA G-Quadruplexes in Kirsten Ras (KRAS) Oncogene as Targets for Small Molecules Inhibiting Translation. J. Med. Chem. 2017, 60, 9448-9461. [CrossRef]

11. Tikhomirov, A.S.; Tsvetkov, V.B.; Kaluzhny, D.N.; Volodina, Y.L.; Zatonsky, G.V.; Schols, D.; Shchekotikhin, A.E. Tri-armed ligands of G-quadruplex on heteroarene-fused anthraquinone scaffolds: Design, synthesis and pre-screening of biological properties. Eur. J. Med. Chem. 2018, 159, 59-73. [CrossRef] [PubMed]

12. Tikhomirov, A.S.; Lin, C.Y.; Volodina, Y.L.; Dezhenkova, L.G.; Tatarskiy, V.V.; Schols, D.; Shtil, A.A.; Kaur, P.; Chueh, P.J.; Shchekotikhin, A.E. New antitumor anthra[2,3-b]furan-3-carboxamides: Synthesis and structure-activity relationship. Eur. J. Med. Chem. 2018, 148, 128-139. [CrossRef]

13. Chueh, P.J.; Kim, C.; Cho, N.; Morré, D.M.; Morré, D.J. Molecular cloning and characterization of a tumor-associated, growth-related, and time-keeping hydroquinone (NADH) oxidase (tNOX) of the HeLa cell surface. Biochemistry 2002, 41, 3732-3741. [CrossRef] [PubMed] 
14. Morré, D.J. NADH oxidase: A multifunctional ectoprotein of the eukaryotic cell surface. In Plasma Membrane Redox Systems and Their Role in Biological Stress and Disease; Asard, H., Bérczi, A., Caubergs, R., Eds.; Kluwer Academic Publishers: Dordrecht, The Netherlands, 1998; pp. 121-156.

15. Chueh, P.J. Cell membrane redox systems and transformation. Antioxid. Redox Signal. 2000, 2, $177-187$. [CrossRef]

16. Cheng, H.L.; Lee, Y.H.; Yuan, T.M.; Chen, S.W.; Chueh, P.J. Update on a tumor-associated NADH oxidase in gastric cancer cell growth. World J. Gastroenterol. 2016, 22, 2900-2905. [CrossRef]

17. Chueh, P.J.; Wu, L.Y.; Morre, D.M.; Morre, D.J. tNOX is both necessary and sufficient as a cellular target for the anticancer actions of capsaicin and the green tea catechin (-)-epigallocatechin-3-gallate. Biofactors 2004, 20, 235-249.

18. Liu, S.C.; Yang, J.J.; Shao, K.N.; Chueh, P.J. RNA interference targeting tNOX attenuates cell migration via a mechanism that involves membrane association of Rac. Biochem. Biophys. Res. Commun. 2008, 365, 672-677. [CrossRef] [PubMed]

19. Wang, H.M.; Chuang, S.M.; Su, Y.C.; Li, Y.H.; Chueh, P.J. Down-regulation of tumor-associated NADH oxidase, tNOX (ENOX2), enhances capsaicin-induced inhibition of gastric cancer cell growth. Cell Biochem. Biophys. 2011, 61, 355-366. [CrossRef]

20. Zeng, Z.M.; Chuang, S.M.; Chang, T.C.; Hong, C.W.; Chou, J.C.; Yang, J.J.; Chueh, P.J. Phosphorylation of serine-504 of tNOX (ENOX2) modulates cell proliferation and migration in cancer cells. Exp. Cell Res. 2012, 318, 1759-1766. [CrossRef]

21. Lin, M.H.; Lee, Y.H.; Cheng, H.L.; Chen, H.Y.; Jhuang, F.H.; Chueh, P.J. Capsaicin Inhibits Multiple Bladder Cancer Cell Phenotypes by Inhibiting Tumor-Associated NADH Oxidase (tNOX) and Sirtuin1 (SIRT1). Molecules 2016, 21, 849. [CrossRef] [PubMed]

22. Morre, D.J.; Chueh, P.J.; Morre, D.M. Capsaicin inhibits preferentially the NADH oxidase and growth of transformed cells in culture. Proc. Natl. Acad. Sci. USA 1995, 92, 1831-1835. [CrossRef] [PubMed]

23. Morré, D.J.; Bridge, A.; Wu, L.Y.; Morré, D.M. Preferential inhibition by (-)-epigallocatechin-3-gallate of the cell surface NADH oxidase and growth of transformed cells in culture. Biochem. Pharmacol. 2000, 60, 937-946. [CrossRef]

24. Su, Y.C.; Lin, Y.H.; Zeng, Z.M.; Shao, K.N.; Chueh, P.J. Chemotherapeutic agents enhance cell migration and epithelial-to-mesenchymal transition through transient up-regulation of tNOX (ENOX2) protein. Biochim. Biophys. Acta 2012, 1820, 1744-1752. [CrossRef]

25. Chen, H.Y.; Cheng, H.L.; Lee, Y.H.; Yuan, T.M.; Chen, S.W.; Lin, Y.Y.; Chueh, P.J. Tumor-associated NADH oxidase (tNOX)-NAD+-sirtuin 1 axis contributes to oxaliplatin-induced apoptosis of gastric cancer cells. Oncotarget 2017, 8, 15338-15348. [CrossRef]

26. Bruno, M.; Brightman, A.O.; Lawrence, J.; Werderitsh, D.; Morré, D.M.; Morré, D.J. Stimulation of NADH oxidase activity from rat liver plasma membranes by growth factors and hormones is decreased or absent with hepatoma plasma membranes. Biochem. J. 1992, 284 Pt 3, 625-628. [CrossRef]

27. Lee, Y.H.; Chen, H.Y.; Su, L.J.; Chueh, P.J. Sirtuin 1 (SIRT1) Deacetylase Activity and NAD ${ }^{+} /$NADH Ratio $^{2}$ Are Imperative for Capsaicin-Mediated Programmed Cell Death. J. Agric. Food Chem. 2015, 63, 7361-7370. [CrossRef]

28. Lujambio, A.; Akkari, L.; Simon, J.; Grace, D.; Tschaharganeh, D.F.; Bolden, J.E.; Zhao, Z.; Thapar, V.; Joyce, J.A.; Krizhanovsky, V.; et al. Non-cell-autonomous tumor suppression by p53. Cell 2013, 153, 449-460. [CrossRef] [PubMed]

29. Singal, P.K.; Iliskovic, N. Doxorubicin-induced cardiomyopathy. N. Engl. J. Med. 1998, 339, 900-905. [CrossRef]

30. Renu, K.; V, G.A.; P, B.T.; Arunachalam, S. Molecular mechanism of doxorubicin-induced cardiomyopathy-An update. Eur. J. Pharmacol. 2018, 818, 241-253. [CrossRef]

31. Savitski, M.M.; Reinhard, F.B.; Franken, H.; Werner, T.; Savitski, M.F.; Eberhard, D.; Martinez Molina, D.; Jafari, R.; Dovega, R.B.; Klaeger, S.; et al. Tracking cancer drugs in living cells by thermal profiling of the proteome. Science 2014, 346, 1255784. [CrossRef]

32. Martinez Molina, D.; Jafari, R.; Ignatushchenko, M.; Seki, T.; Larsson, E.A.; Dan, C.; Sreekumar, L.; Cao, Y.; Nordlund, P. Monitoring drug target engagement in cells and tissues using the cellular thermal shift assay. Science 2013, 341, 84-87. [CrossRef] [PubMed] 
33. Sanchez-Ruiz, J.M. Ligand effects on protein thermodynamic stability. Biophys. Chem. 2007, 126, 43-49. [CrossRef]

34. Ewer, M.S.; Ewer, S.M. Cardiotoxicity of anticancer treatments: What the cardiologist needs to know. Nat. Rev. Cardiol. 2010, 7, 564-575. [CrossRef]

35. Swain, S.M.; Whaley, F.S.; Ewer, M.S. Congestive heart failure in patients treated with doxorubicin-A retrospective analysis of three trials. Cancer 2003, 97, 2869-2879. [CrossRef]

36. Harake, D.; Franco, V.I.; Henkel, J.M.; Miller, T.L.; Lipshultz, S.E. Cardiotoxicity in childhood cancer survivors: Strategies for prevention and management. Future Cardiol. 2012, 8, 647-670. [CrossRef]

37. Gorini, S.; De Angelis, A.; Berrino, L.; Malara, N.; Rosano, G.; Ferraro, E. Chemotherapeutic Drugs and Mitochondrial Dysfunction: Focus on Doxorubicin, Trastuzumab, and Sunitinib. Oxid. Med. Cell. Longev. 2018. [CrossRef] [PubMed]

38. Simunek, T.; Sterba, M.; Popelova, O.; Adamcova, M.; Hrdina, R.; Gersl, V. Anthracycline-induced cardiotoxicity: Overview of studies examining the roles of oxidative stress and free cellular iron. Pharmacol. Rep. 2009, 61, 154-171. [CrossRef]

39. Morre, D.J.; Korty, T.; Meadows, C.; Ades, L.M.; Morre, D.M. ENOX2 target for the anticancer isoflavone ME-143. Oncol. Res. 2014, 22, 1-12. [CrossRef]

40. Morre, D.J.; Chueh, P.J.; Yagiz, K.; Balicki, A.; Kim, C.; Morre, D.M. ECTO-NOX target for the anticancer isoflavene phenoxodiol. Oncol. Res. 2007, 16, 299-312. [CrossRef]

41. Chen, H.Y.; Islam, A.; Yuan, T.M.; Chen, S.W.; Liu, P.F.; Chueh, P.J. Regulation of tNOX expression through the ROS-p53-POU3F2 axis contributes to cellular responses against oxaliplatin in human colon cancer cells. J. Exp. Clin. Cancer Res. 2018, 37, 161. [CrossRef]

42. Mao, L.C.; Wang, H.M.; Lin, Y.Y.; Chang, T.K.; Hsin, Y.H.; Chueh, P.J. Stress-induced down-regulation of tumor-associated NADH oxidase during apoptosis in transformed cells. FEBS Lett. 2008, 582, 3445-3450. [CrossRef]

43. Adlakha, Y.K.; Saini, N. miR-128 exerts pro-apoptotic effect in a p53 transcription-dependent and -independent manner via PUMA-Bak axis. Cell Death Dis. 2013, 4, e542. [CrossRef]

44. Nebbioso, A.; Carafa, V.; Conte, M.; Tambaro, F.P.; Abbondanza, C.; Martens, J.; Nees, M.; Benedetti, R.; Pallavicini, I.; Minucci, S.; et al. c-Myc Modulation and Acetylation Is a Key HDAC Inhibitor Target in Cancer. Clin. Cancer Res. 2017, 23, 2542-2555. [CrossRef] [PubMed]

45. Kim, H.B.; Kim, M.J.; Lee, S.H.; Lee, J.W.; Bae, J.H.; Kim, D.W.; Dao, T.T.; Oh, W.K.; Kang, C.D.; Kim, S.H. Amurensin G, a novel SIRT1 inhibitor, sensitizes TRAIL-resistant human leukemic K562 cells to TRAIL-induced apoptosis. Biochem. Pharmacol. 2012, 84, 402-410. [CrossRef] [PubMed]

46. Yuan, J.; Minter-Dykhouse, K.; Lou, Z. A c-Myc-SIRT1 feedback loop regulates cell growth and transformation. J. Cell Boil. 2009, 185, 203-211. [CrossRef]

47. Menssen, A.; Hydbring, P.; Kapelle, K.; Vervoorts, J.; Diebold, J.; Luscher, B.; Larsson, L.G.; Hermeking, H. The c-MYC oncoprotein, the NAMPT enzyme, the SIRT1-inhibitor DBC1, and the SIRT1 deacetylase form a positive feedback loop. Proc. Natl. Acad. Sci. USA 2012, 109, E187-E196. [CrossRef] [PubMed]

48. Hong, K.S.; Park, J.I.; Kim, M.J.; Kim, H.B.; Lee, J.W.; Dao, T.T.; Oh, W.K.; Kang, C.D.; Kim, S.H. Involvement of SIRT1 in hypoxic down-regulation of c-Myc and beta-catenin and hypoxic preconditioning effect of polyphenols. Toxicol. Appl. Pharmacol. 2012, 259, 210-218. [CrossRef]

49. Kim, M.J.; Hong, K.S.; Kim, H.B.; Lee, S.H.; Bae, J.H.; Kim, D.W.; Dao, T.T.; Oh, W.K.; Kang, C.D.; Kim, S.H. Ku70 acetylation and modulation of c-Myc/ATF4/CHOP signaling axis by SIRT1 inhibition lead to sensitization of HepG2 cells to TRAIL through induction of DR5 and down-regulation of c-FLIP. Int. J. Biochem. Cell B 2013, 45, 711-723. [CrossRef] [PubMed]

50. Huffman, D.M.; Grizzle, W.E.; Bamman, M.M.; Kim, J.S.; Eltoum, I.A.; Elgavish, A.; Nagy, T.R. SIRT1 is significantly elevated in mouse and human prostate cancer. Cancer Res. 2007, 67, 6612-6618. [CrossRef] [PubMed]

51. Liu, T.; Liu, P.Y.; Marshall, G.M. The critical role of the class III histone deacetylase SIRT1 in cancer. Cancer Res. 2009, 69, 1702-1705. [CrossRef] [PubMed]

52. Morré, D.J.; Caldwell, S.; Mayorga, A.; Wu, L.Y.; Morré, D.M. NADH oxidase activity from sera altered by capsaicin is widely distributed among cancer patients. Arch. Biochem. Biophys. 1997, 342, 224-230. [CrossRef] 
53. Chueh, P.J.; Morre, D.J.; Wilkinson, F.E.; Gibson, J.; Morré, D.M. A 33.5-kDa heat- and protease-resistant NADH oxidase inhibited by capsaicin from sera of cancer patients. Arch. Biochem. Biophys. 1997, 342, $38-47$. [CrossRef] [PubMed]

54. Ronconi, G.; Lessiani, G.; Spinas, E.; Kritas, S.K.; Caraffa, A.; Saggini, A.; Antinolfi, P.; Pizzicannella, J.; Toniato, E.; Conti, P. ENOX2 (or tNOX): A new and old molecule with cancer activity involved in tumor prevention and therapy. J. Biol. Regul. Homeost. Agents 2016, 30, 649-653. [PubMed]

55. Nelson, R.L.; Dollear, T.; Freels, S.; Persky, V. The relation of age, race, and gender to the subsite location of colorectal carcinoma. Cancer 1997, 80, 193-197. [CrossRef]

56. Yang, Y.; Wang, G.; He, J.; Ren, S.; Wu, F.; Zhang, J.; Wang, F. Gender differences in colorectal cancer survival: A meta-analysis. Int. J. Cancer 2017, 141, 1942-1949. [CrossRef]

57. van Kempen, L.C.L.; Redpath, M.; Elchebly, M.; Klein, K.O.; Papadakis, A.I.; Wilmott, J.S.; Scolyer, R.A.; Edqvist, P.H.; Ponten, F.; Schadendorf, D.; et al. The protein phosphatase 2A regulatory subunit PR70 is a gonosomal melanoma tumor suppressor gene. Sci. Transl. Med. 2016, 8. [CrossRef]

58. Matsuyama, T.; Ishikawa, T.; Mogushi, K.; Yoshida, T.; Iida, S.; Uetake, H.; Mizushima, H.; Tanaka, H.; Sugihara, K. MUC12 mRNA expression is an independent marker of prognosis in stage II and stage III colorectal cancer. Int. J. Cancer 2010, 127, 2292-2299. [CrossRef]

59. Canadas, I.; Rojo, F.; Taus, A.; Arpi, O.; Arumi-Uria, M.; Pijuan, L.; Menendez, S.; Zazo, S.; Domine, M.; Salido, M.; et al. Targeting epithelial-to-mesenchymal transition with Met inhibitors reverts chemoresistance in small cell lung cancer. Clin. Cancer Res. 2014, 20, 938-950. [CrossRef] [PubMed]

60. Swoboda, A.; Schanab, O.; Tauber, S.; Bilban, M.; Berger, W.; Petzelbauer, P.; Mikula, M. MET expression in melanoma correlates with a lymphangiogenic phenotype. Hum. Mol. Genet. 2012, 21, 3387-3396. [CrossRef]

61. Chen, C.F.; Huang, S.; Liu, S.C.; Chueh, P.J. Effect of polyclonal antisera to recombinant tNOX protein on the growth of transformed cells. Biofactors 2006, 28, 119-133. [CrossRef] [PubMed]

(C) 2019 by the authors. Licensee MDPI, Basel, Switzerland. This article is an open access article distributed under the terms and conditions of the Creative Commons Attribution (CC BY) license (http:/ / creativecommons.org/licenses/by/4.0/). 